\section{Analytical Applications of the High Sensitive Polarograph} (Part 2)

Determination of Cadmium in High-purity Indium Metal

Hiroyosi Uehara

Mitsui Mining \& Smelting Co., Central Research Latoratories.

\section{1. 緒言}

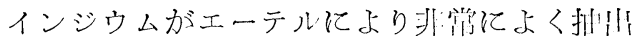

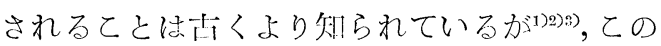
推川江走店用してインジウム此全川のカドミウ ムを定量するととを試みた。

この方法により從来より婯易に $1 \mathrm{ppm}$ 程度 迄のカドミウムの定量が行えるようになつた。

\section{2. 試薬および裝置}

カドミウム標準溶液 : カドミウム地食(99.99 \%) $1.000 \mathrm{~g}$ を矿朘約 $10 \mathrm{ml}$ を四いて溶解し,

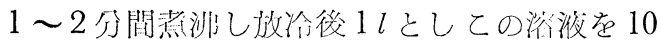
㒉打よび 100 熖飞うすぬ $100 \mu \mathrm{g} / \mathrm{ml}$ 扎与び $10 \mu$

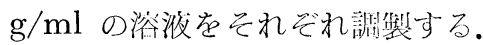

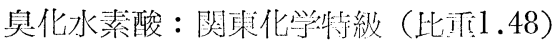

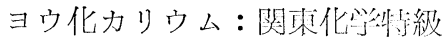

イソプロピルエーテル : 利光純染 1 級

な打使用したポーラログラフ出南黛度ポーラ ログラフ（柳本製）扎よび父䤈闻用ポラログラ

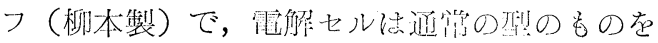
用い対極は水銀プールとした。

液温は $25 \pm 0.5^{\circ} \mathrm{C}$ で滴下極は $1 \mathrm{M}$ ヨウ化カリ ウム漟液で $\mathrm{t}=2.5 \mathrm{sec}, \mathrm{m}=1.57 \mathrm{mg} / \mathrm{sec}$. であ る.

また抽以の際の振とう時閂㤁 1 分閆とした。

\section{3. 実験}

3.1 抽出によるカドそウムとインジウムと の分離

3.1 .1 臭化水素酸の滥度打よびイソプロピ ルエーテルの使用量によるインジウ
高感度ポーラログラフの応用

(第 2 郝)

高純度インジウム此金打の

カドミウムの定貫

上原 博 義

三井金属鈗栄粎式会社

中央研究所

ム抽山洨の変化

インジウムは贪化水素酸䣼性でエーテル原に

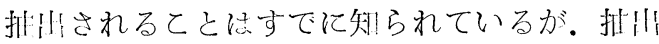
に使用するイソプロピルエーテルの量佶よび抽 出のさいの臭化水素酸の港度の影㗽についてし らべた。すなわち，インジウム $1 \mathrm{~g}$ を臭化水素 酸約 $\mathrm{Cml}$ 飞浴解したのち浚量を約 $20 \mathrm{ml}$ とす る。乞の際臭化水素酸の涯度を 4，5，6 打よ び7 M と変え，また 1 同の抽似使用するイソ プロピルエーテルの量を $10 \mathrm{ml}$ としとの使用回 数を $1 ， 2$ ，扎よび 3 山とした埸合のインジウ

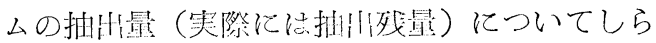
ベた絓果を Fig. 1 に示した。

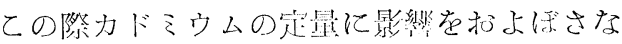
いインジウムの存在量は約 $0.1 \%$ (約 $1 \mathrm{mg}$ ）で

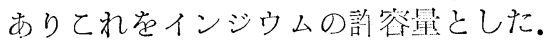

したがつてインジウム $1 \mathrm{~g}$ を似用した埸会は Fig.1 よりわかるごとくその許罍星以下となる 条件活 $5 \mathrm{M}$ の息化水素酸で蛙イソ゚ロピルエー テル $30 \mathrm{ml} ， 6$ 打よび $7 \mathrm{M}$ 臭化水素酸ではイ ソプロピルエーテル 20 または $30 \mathrm{ml}$ である.

3.12 抽出操作によるカドミウムのロスにつ いて

3.1 .1 の実駼紶果よりインジウムは臭化水素 瑴ーイソプロピルエーテルにより非常によく抽 出されることがわかつたが，乙の際の抽捗によ るカドミウムのロスについてしらべた。すなわ ち，臭化水素酸の浱度とカドミウムの量预よび インジウムの量を変えて実験を行つた絬果を Table 1 に示した.

Table 1 より抽出によるカドミウムのロスは 


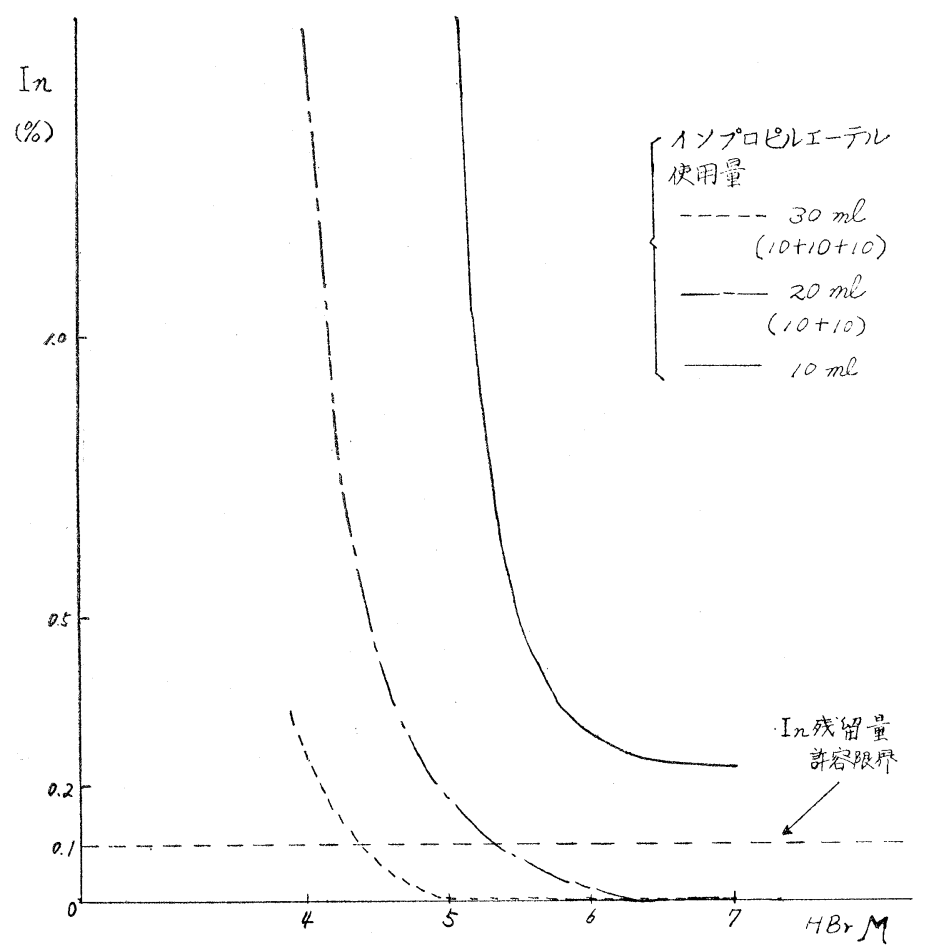

Fig. $1 \mathrm{HBr}$ の各濃度に於ける In の抽出率 (残留率)

Table 1 臭化水素酸の濃度打よびインジウムの影響

\begin{tabular}{ccccc}
\hline $\begin{array}{c}\mathrm{HBr} \\
(\mathrm{M})\end{array}$ & $\begin{array}{c}\mathrm{Cd} \\
(\mu \mathrm{g})\end{array}$ & $\begin{array}{c}\text { In } \\
(\mathrm{g})\end{array}$ & $\begin{array}{c}\text { 測定量 } \\
(\mu \mathrm{g})\end{array}$ & $\begin{array}{c}\text { 請差 } \\
(\%)\end{array}$ \\
\hline 5 & 100 & 0 & 106 & +6 \\
$\prime \prime$ & 200 & $\prime \prime$ & 194 & -3 \\
$\prime \prime$ & 300 & $\prime \prime$ & 295 & -1.7 \\
$\prime \prime$ & 100 & 1.0 & 105 & +5 \\
$\prime \prime$ & 200 & $\prime \prime$ & 208 & +4 \\
$\prime \prime$ & 300 & $\prime \prime$ & 299 & -0.3 \\
6 & 100 & 0 & 97 & -3 \\
$\prime \prime$ & 200 & $\prime \prime$ & 194 & -3 \\
$\prime \prime$ & 300 & $\prime \prime$ & 297 & -1 \\
$\prime \prime$ & 100 & 1.0 & 109 & +9 \\
$\prime \prime$ & 200 & $\prime \prime$ & 205 & +2.5 \\
$\prime \prime$ & 300 & $\prime \prime$ & 289 & -3.7 \\
\hline
\end{tabular}

ほとんどなく，インジウムの影響も見られな い. また臭化水素酸传 $5 \mathrm{M}$ でも $6 \mathrm{M}$ でも大差 ない様である。

\section{1 .3 共存可万他元素の挙動}

インジウム地全中に含まれているカドミウム 以外のイ純物结主として銠，釷，銅，タリウム
錫，ニッケルであるがてのうち鉄とタリウムは インジウムと共にイソプロピルエーテルにより 抽们される。

\section{2 基礎液について}

主成分のインジウム虫抽惟よりカドミウム と分離するととが业来るが，な打カドミウムの

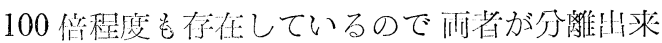

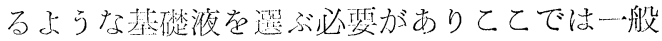

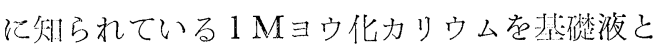
して使用した ${ }^{4) 5}$ ， 乙の溶液に括けるカドミウム の岥電位结-0.75V (vs S.G.E.) である.

\section{2 .1 臭化水素陵扢よび硫酸の影響}

インジウムを抽出除去した浴液は主としてカ ドミウムを含む $5 \mathrm{M}$ 臭化水素酸である.

これそ值ちにヨウ化カリウムを加えても臭化 水素陸の彷害によりカド之ウムの波形は得られ

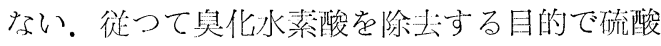

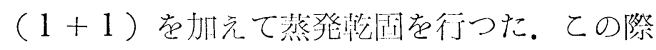
四流将ーラログラフでは硫陵の残星が䭪加する に挝つてカドミウムの波形が望くなる。交流ポ 

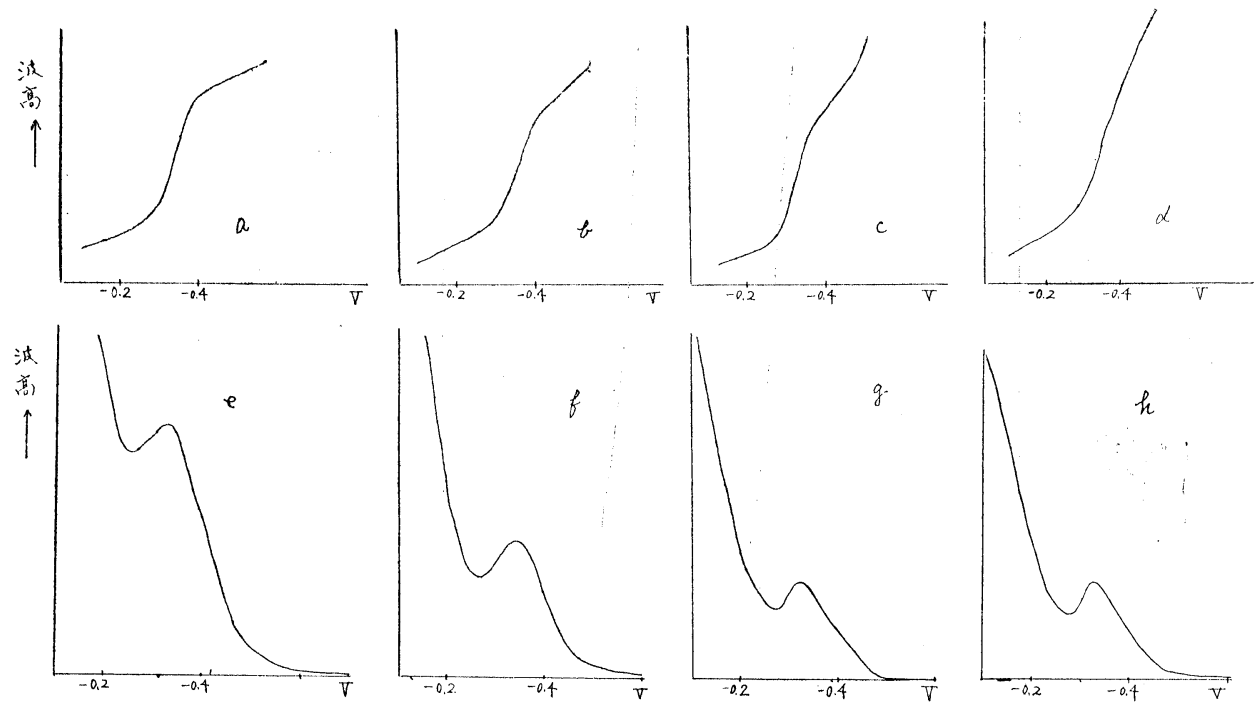

Fig. 2 硫 酸 の 影 響

$$
\begin{aligned}
& \text { a, b, c, d D.C. Polarogram, e, f, g, h A.C. Polarogram } \\
& \text { (感度 } 0.01 \mu \mathrm{A} / \mathrm{mm} \text { ) (A.C. } 30 \mathrm{mV}, 200 \bowtie \text { ) } \\
& \text { a,e : } \mathrm{H}_{2} \mathrm{SO}_{4} \text { 乾固 b,f: } \mathrm{H}_{2} \mathrm{SO}_{4}(1+1) 2 \mathrm{ml} \\
& \text { c,g: } \mathrm{H}_{2} \mathrm{SO}_{4}(1+1) 4 \mathrm{ml} \text { d,h : } \mathrm{H}_{2} \mathrm{SO}_{4}(1+1) 6 \mathrm{ml}
\end{aligned}
$$

|ラログラフでは硫酸の量が相当多量になつて も测定できなくなるようなととはないが，波高 が炏第に低くなる。

乾固した場合が波高は最も高いが同時に蓄雷 器電流も增加する. Fig. 2 にこの状䈍を示す。 しかし硫酸の残量が多い程ヨウ化力りウムが分 解される。

この結果加える硫䧈の量はできるだけ少ない 方がよい，挝つてここでは硫陖 $(1+1)$ の添 加量は $3 \mathrm{ml}$ としできるだけ蒸癷乾国を行つた。

\section{2 .2 其存ずる他元素の影維}

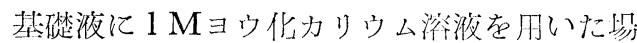
合には鉄，銓，鉛，錫，タリウム扎よびニッケ ルは勿論インジウムもその波電位が，カドミ ウムのそれと $0.1 \mathrm{~V}$ 以上離れているのでカド之 ウムの定量に妨害しないと考えられる。Table 2 にこれら不純物の影響を示した。

Table 2 より乙れらの共存元素の影留はほと んどないととがわかる。

\section{4. 分析操作拉よび分析結果}

4.1 インジウム地全中のカドミウムの分析法
Table 2 不純物の影㗽

\begin{tabular}{cccccccccc}
\hline & \multicolumn{1}{c}{ 不純物の量 } & \multicolumn{3}{c}{ 添加是 定显值 } \\
\cline { 2 - 9 } No. & $\mathrm{Fe}$ & $\mathrm{Gu}$ & $\mathrm{Pb}$ & $\mathrm{Sn}$ & $\mathrm{Tl}$ & $\mathrm{Ni}$ & $\mathrm{Cd}$ & $\mathrm{Cd}$ \\
& $(\mu \mathrm{g})$ & $(\mu \mathrm{g})$ & $(\mu \mathrm{g})$ & $(\mu \mathrm{g})$ & $(\mu \mathrm{g})$ & $(\mu \mathrm{g})$ & $(\mu \mathrm{g})$ & $(\mu \mathrm{g})$ \\
\hline 1 & 100 & 100 & 100 & 100 & 100 & 100 & 100 & 99.1 \\
2 & $\prime \prime$ & $\prime \prime$ & $\prime \prime$ & $\prime \prime$ & $\prime \prime$ & $\prime \prime$ & 100 & 84.6 \\
3 & $\prime \prime$ & $\prime \prime$ & $\prime \prime$ & $\prime \prime$ & $\prime \prime$ & $\prime \prime$ & 200 & 201.6 \\
4 & $\prime \prime$ & $\prime \prime$ & $\prime \prime$ & $\prime \prime$ & $\prime \prime$ & $\prime \prime$ & 200 & 199.0 \\
\hline
\end{tabular}

武料 $1 \mathrm{~g}$ をビーカー（容最 $100 \mathrm{ml}$ ) にはかり

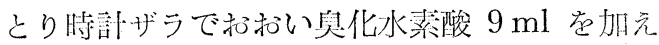
たのち徐熱して完全に溶解与る。（この別合の 試料浴液の臭化水素酸莄度は約 $5 \mathrm{M}$ である.) ての溶液を分液ロート（容量 $100 \mathrm{ml}$ ) 飞移し入 れ，もとのビーカーは $5 \mathrm{M}$ 臭化水素泼約 $10 \mathrm{ml}$ を用いて洗涤したのち，イソプロピルエーテル $10 \mathrm{ml}$ を加え 1 分間振とうする.

試料浴液はエーテル層と分離する。乙の際別 に分液ロートを用意して扣き分離される試料溶 液はこれに受ける。乙れに再びイソプロピルエ 一テルを命司と同量加え，前回の操作を繰返し て行う。ての操作を合計 3 回行つた後使用した 
エーテル刚合部を一緒にして分液ロートに移 し人れ，乙れに $5 \mathrm{M}$ 臭化水素酸を $5 \mathrm{ml}$ を加光

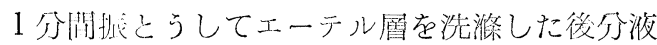
する。

この條作在 2 四繰返して行い。乙の洗深に使 用した具化水素酸䛱武料溶液に合する。乙れに 硫䧈 $(1+1)$ 約 $3 \mathrm{ml}$ 加光，加熱蒸発してほ とんど些们する。放冷後てれに水約 $10 \mathrm{ml}$ を加 えて㳩滥し，塩類を溶解したのち $50 \mathrm{ml}$ のメス フラスコに移し人れ，5M ウウ化カリウム溶淮 $10 \mathrm{ml}$ 师光，水を用いて正しく $50 \mathrm{ml}$ とする.

この溶淮の一部を電解恆に移し入れ等素ガス を約10分阔通じ溶存酸素を追い出したのち恒

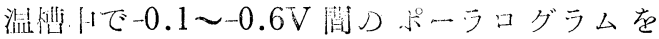
求凶る.

\section{2 分析結果}

以上の分析方法によりカドミウムの定量を行 つた結果を Table 3 に示す.
Table 3 分 析 結 果

\begin{tabular}{|c|c|c|}
\hline 試 & $\mathrm{Cd} \%$ & 考 \\
\hline Tadanac & $0.011^{*}$ & Tadanac0分忻絬果 \\
\hline $99.95 \%$ In & $0.011^{*}$ & $\operatorname{Cd} 0.01 \%$ \\
\hline Tadanac & 0.00023 & Tadanacの分析絬果 \\
\hline $99.999 \%$ In & 0.00017 & Cd $0.0002 \%$ \\
\hline M社製品 (A) & $0.0082^{*}$ & \\
\hline M社製品 (B) & $0.0015_{5}^{*}$ & \\
\hline 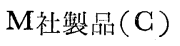 & 0.0003 & \\
\hline
\end{tabular}

*印は直流ポーラログラフ使用.

\section{文献}

1) I. Wada and R. Ishi : Sci. Papers Inst. Phys. Chem. Research (Tokyo), 34, 787 (1938)

2) S. Kitahara : Repts. Sci. Res. Inst. (Japan), 25, 165 (1949)

3) F.A. Pohl und W. Bonsels : Z. Anal. Ghem. 108, (1957)

4) A.A. Vlcek : 無機復極剂半波電位表 (1956)

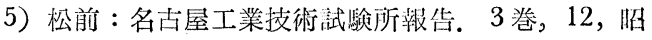
和29年

(ReceivedMay25,1959)

\section{会告}

\section{高感度ポーラログラフ研究会（東京）}

前罗会告で扣しらせ致しました上記研究会について 6 月22日あらためて発足打合せ会が東京

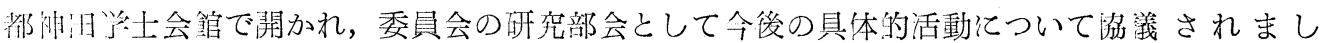
た．本河究会の参加者には委員会に加入していたづき（会誌溝読），その活動内容は高感晏ポ 一ラログラフ分析に関する研究，又はそれに関連した形究を行つている者によつて構成し，高 感变ポーラログラフ分析を中心とし，必要㐫じて他の高感变分析法化ついて討論する様な会 にするととになりました，具本的な事業としてはさしあたり，集談会，ゼミナ一，文献紹介等

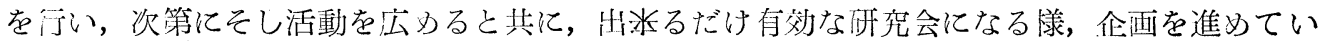

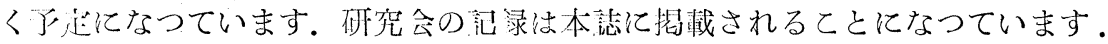

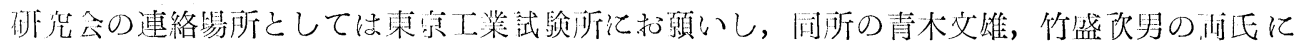
中心的な非活人として今後の会の運営について御虫話領う予走になつています。

\section{Dr. R. Pribil 講 演 会}

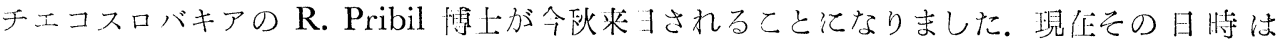

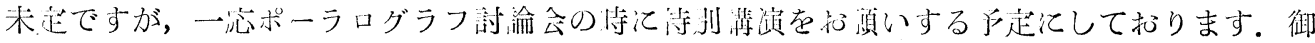
期待下さい. 